\title{
Editorial
}

\section{Medical History takes a Partner}

The first decade of the twenty-first century is becoming a decade of significant change for Medical History. In the past five years the journal has acquired new editors, joined the electronic age with free on-line access, and taken a stand on authors' rights by returning copyright in articles and book reviews to authors. Now, in 2006, the journal goes into partnership. We are proud to announce that with this issue, Medical History becomes the official journal of the European Association for the History of Medicine and Health. Established in 1991 with funding from the European Union, the EAHMH (as it is more generally known) is a lively organization with a worldwide membership. The Association is based in Strasbourg, a city whose rich Franco/German heritage provides it with such impeccable international credentials that it is currently the seat also of the Council of Europe, the European Court of Human Rights and the European Parliament. Martin Bucer, one of the leaders of the Reformation and a close friend of Martin Luther, was a native of Strasbourg; in 1792, the city became the birthplace of France's national anthem, 'La marseillaise'. For all this strong European context, the EAHMH is by no means an exclusively European forum: its declared object is to look outwards to all fields of interest and research in the history of health and medicine. It has members in countries from North America to Australia, and an interdisciplinary focus that attracts demographers, social anthropologists and social historians as well as medical men and historians of medicine. The Association is governed by the Council and Scientific Board, comprising eleven members, whose President is currently Professor Virginia Berridge of the London School of Hygiene and Tropical Medicine. Three members of the Scientific Board will have seats on the Editorial Board of Medical History. Professor Aina Schiøtz (University of Bergen, Norway) and Professor Volker Roelke (University of Giessen, Germany) were appointed to the Editorial Board already in 2003, and they are joined by Professor Fernando Salmón (Universidad de Cantabria in Santander, Spain). Additionally, the Board will receive an annual report from the editors of the journal, and the Evening Lecture delivered at the meetings of the EAHMH will be published in Medical History and the other plenary lectures may be, along with any notices required by the Association. The EAHMH meets bi-annually, most recently in Paris in September 2005, where scholars from Europe, the United States, South America, Canada, India, Australia, Israel, New Zealand, Malta, Japan and Iran enjoyed an exciting and stimulating three days in the beautiful buildings of the Ministry of Research, and the Ecole des Hautes Etudes en Sciences Sociales. The Eighth bi-annual conference will take place in September 2007, and will be hosted by the London School of Hygiene and Tropical Medicine in London. Further details of the EAHMH and its meetings can be found on http://www.eahmh.net.

The new partnership between Medical History and the EAHMH does not mean that the journal will be turning its back on old and valued colleagues, contributors and readers in the world beyond Europe; rather we hope that the journal will broaden and deepen its international focus to the enrichment of our discipline. In particular, we hope that 
colleagues whose first language is not English will be encouraged to seek to publish with Medical History, that their work may more easily reach out to and inform the international history of medicine community, and that the journal may help to promote the international exchange of scholarly ideas and enterprise. As Editors we are excited by this new venture and the opportunities it offers, and we look forward to working with the EAHMH and its membership worldwide. 